\title{
Development of a New Air Spring Dynamic Model
}

Viktor Gavriloski

Professor

Ss. Cyril and Methodius University in Skopje Faculty of Mechanical Engineering

Jovana Jovanova

Teaching Assistant Ss. Cyril and Methodius University in Skopje Faculty of Mechanical Engineering

\section{Goce Tasevski}

Teaching Assistant Ss. Cyril and Methodius University in Skopje Faculty of Mechanical Engineering

\section{Marjan Djidrov}

Teaching Assistant Ss. Cyril and Methodius University in Skopje Faculty of Mechanical Engineering
The design of automotive suspension systems involves compromise between the ride quality and driving stability. The change of the damping and stiffness coefficients could provide adaptive characteristic of the suspension system. Air springs, as suspension elements, could provide change of the stiffness coefficient by simply including or excluding additional volumes and thus could provide a controlled variable spring rate. Study of the influence of air springs on the vehicle vertical dynamics, requires use of dynamic air spring models. This paper deals with air spring models. Dynamic model of an air spring with frequency dependent characteristics is presented. The flow resistance in air springs is present when two volumes are connected and it depends on the design characteristics of the connecting pipeline. In order to have the dynamic model without many experimentally obtained parameters, the methodology for defining flow resistance coefficients is developed and presented in this paper. The verification of the dynamic air spring model is done by an experiment. The simulation and experimental results are analysed.

Keywords: air spring, dynamic model, vehicle suspension system, damping coefficients

\section{INTRODUCTION}

One of the basic systems in a vehicle is the suspension system. The design of automotive suspension systems involves a number of compromises. The main compromise is between the ride quality and driving stability because, on one side, the suspension must be soft to obtain a good level of ride comfort and at the same time must be firm to maintain good tire to ground contact in order to ensure safety. The design of a passive suspension system is a compromise between these conflicting demands. In order to maintain the level of comfort that customers expect from vehicles, and still to maintain high safety standards of automobiles, suspension designers have been forced to look beyond conventional suspension systems.

One of the possible solutions for suspension system with possible application in passenger vehicles could consist of a continuously variable semi-active damper and air spring with additional volumes. Semi-active suspensions contain damping elements whose properties can be changed by an external control. Semi-active suspension control is based on similar control algorithms, as applied to active suspension systems, but it is only capable of dissipating energy which gives the characteristic of a more energy efficient system. However, the performances of the semi-active suspensions are very competitive to the performances of active suspensions [1,5]. Moreover, in case the

Received: May 2014, Accepted: November 2014

Correspondence to: Viktor Gavriloski, Phd

Faculty of Mechanical Engineering in Skopje,

P.O Box 464, MK-1001 Skopje, Republic of Macedonia

viktor.gavriloski@mf.edu.mk

doi:10.5937/fmet1404305G

(C) Faculty of Mechanical Engineering, Belgrade. All rights reserved controllable damper fails, it will simply revert to a conventional damper.

Air springs, as suspension elements, could provide changing of the stiffness characteristic, depending on the conditions and different height levels. From the design aspect, in conventional suspensions the spring should be stiff enough to prevent the body from dropping too much at full load, which gives disadvantage regarding the ride comfort during normal operation. The ability of re-levelling gives the possibility for air suspensions to be designed softer than conventional suspension in order to provide better ride comfort. Furthermore, this could provide one suspension height for all loads condition, allowing more usable suspension working space.

The air springs are mainly used in commercial vehicles, but recently they are also used in higher classes of passenger vehicles. Current air spring systems exist in combination with hydraulic shock absorbers. However, depending on the design characteristics, some friction could be added and the system could be used not only as a spring but also as a damper.

Despite the fact that the air springs for passenger cars are commercially available, there is not enough research devoted to their dynamic characteristics. Quaglia and Sorly [2] discuss the vehicular air suspensions from the design aspects, but not from the control viewpoint. The research in this area is mainly conducted for commercial vehicles. In [3], a detailed overview of the constructive characteristics and the theoretical assumptions for the processes in the air springs is given, as well as some experimental analyses.

Analyses of the vehicle vertical dynamics show special interest in the frequency domain from 0 to 20 Hz. Classical dynamic models, as well as the 
manufacturer's technical data is for very low frequencies, from 0 to $1 \mathrm{~Hz}$, while the experimental analyses show nonlinear frequency dependence of the mechanical characteristics of the air spring. Presthus in [4] develops a few dynamic air spring models for rail vehicles. The author has developed a nonlinear mathematical air spring model and in the same paper a comparison of simulation results with experimentally obtained ones to support the theory is presented. However, these models are not appropriate for modelling air springs in passenger vehicles because of the very large differences in their design and in the physical characteristics.

In order to analyse the influence of the air spring parameters on the suspension system performance of passenger vehicles, a new dynamic model should be developed. The new model should be as simple as possible and accurate enough to describe all effects in the process. Therefore, a detailed analysis should be done and appropriate approximations should be made.

This paper deals with the development of a new air spring dynamic model that is verified by the experiment. The frequency dependence of the stiffness is taken into account and presence of the friction due to the flow resistance in the connection pipeline is modelled with appropriate approximation.

\section{PRINCIPLE OF OPERATION}

The air spring is a suspension element that consists of two chambers (primary and additional volume) filled with air at a desired pressure $p_{0}$ and connected to each other by the pipeline system. The principal scheme of an air spring is presented in figure 1. Since the stiffness of the air spring depends on the total volume, with an electromagnetic valve the additional volume can be included or excluded from the system, and the stiffness can be changed. The change of the spring stiffness is controlled by an electromagnetic valve, while damping ratio is defined by dimensions and construction characteristics of the interconnection pipeline. The air spring system works with pure air as a spring and as a damper medium. When the system is disposed to vibrations, the gas gets compressed or expanded, and the pressure becomes equal in the primary and the additional volume.

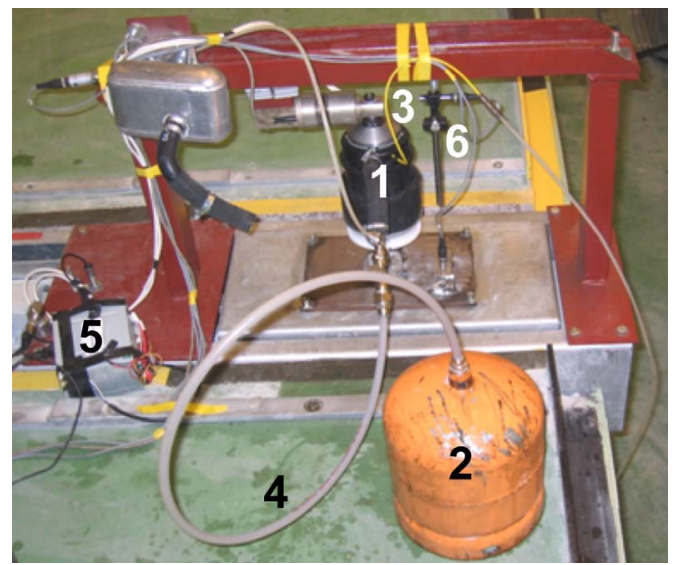

Figure 1. Air spring system [6] 1. Air balloon, 2. Additional volume, 3. Electromagnetic valve, 4. Pipeline, 5. Compressor, 6. Levelling sensor
Considering the dimensions and the construction of the pipeline, there is a phase difference between the pressures in the two volumes which result in dynamic stiffness characteristics.

The air spring systems require air supply equipment and pneumatic control valves, so they need more available space compared to the conventional suspension systems.

The adjustment of the stiffness of the air spring is possible when there is an additional volume and it depends on the size of the balloon, the volume of the additional reservoir and the length and the diameter of the pipeline connecting the two volumes.

Under the vibrations, the behaviour of the compressed air within the air spring system is polytrophic. The minimal stiffness is when there is an isothermal change of the gas state (for frequencies $\mathrm{f}<0.1$ $\mathrm{Hz}$ ), and maximal stiffness is with adiabatic state change (for frequencies $\mathrm{f}>3 \mathrm{~Hz}$ ).

Modelling of an air spring is based on the basics of thermodynamics and fluid dynamics. Although the process itself is quite complex, in the literature the air springs are usually presented with simplified equivalent mechanical models, which gives the possibility of their use in standard multi-body simulation programs for analysing the vehicle behaviour .

\section{MATHEMATICAL MODELS}

In order to analyse the influence of the air spring parameters on the suspension system performance, a dynamic model has been derived. The mathematical model enables dynamic behaviour simulation of the system without experimental determination of too many parameters. The main difference between the classical model and the new, derived one is that in the new model stiffness frequency dependant characteristics are presented. This approach enables control of the suspension system performance by carefully choosing the project parameters.

The modelling of an air spring, presented in this paper, does not take into consideration the levelling system since these changes occur very slowly.

For classical modelling of an air spring, in the literature, the stiffness characteristic is presented by:

$$
c_{z}=\frac{p_{0} n A_{e f}^{2}}{V}
$$

where $p_{0}$ is the absolute pressure in the air spring, $\mathrm{A}_{e f}$ is the effective area, $V$ is the volume of the air balloon and $n$ is the polytrophic coefficient.

The described mathematical model is valid only for low frequencies and does not take into consideration the damping process in the connection pipeline between two volumes. Actually, here the mathematical models incorporate only the stiffness characteristics of the air spring.

In order to incorporate the damping characteristics of air spring into the model, as well as to provide more accurate presentation of the whole process, a new dynamical model has been introduced for the purpose of this research. 
The new dynamic model is based on physical fundamentals and reasonable assumptions. Detailed derivation of the mathematical model is presented in [6]. The equivalent mechanical model that is implemented is shown in figure 2 .

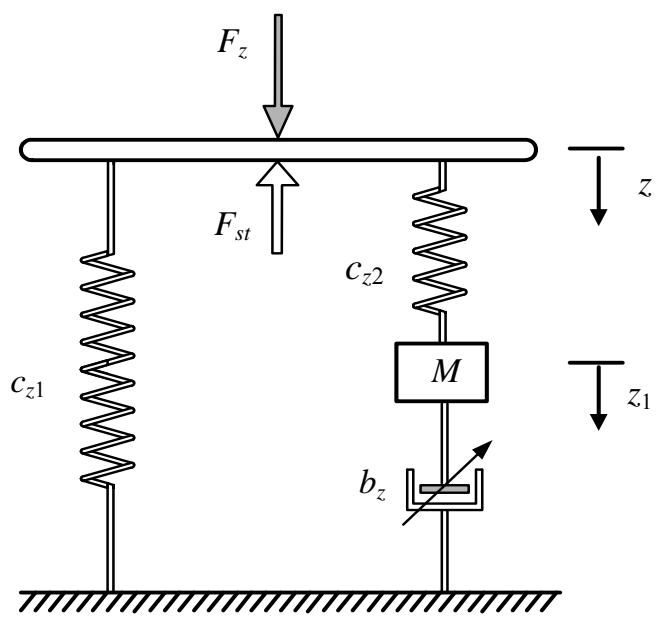

Figure 2. Air spring dynamic model [6]

The dynamical behaviour of the new dynamic model is presented by the following equation:

$$
\begin{aligned}
& F_{z}=F_{s t}+z c_{z 1}+\left(z-z_{1}\right) c_{z 2} \\
& M \ddot{z}_{1}=\left(z-z_{1}\right) c_{z 2}-b_{z} \dot{z}_{1}^{2}
\end{aligned}
$$

The new dynamic model consists of two linear springs $C_{z 1}$ and $C_{z 2}$ that represent the stiffness of the spring; a mass $M$ and a nonlinear viscous damper $b_{z}$. These constants are represented by the following equations:

$$
\begin{gathered}
F_{s t}=\left(p_{0}-p_{a t}\right) A_{e f} \\
c_{z 1}=\frac{p_{0} n A_{e f}^{2}}{V_{B 0}+V_{R 0}} \\
c_{z 2}=\frac{p_{0} n A_{e f}^{2}}{V_{B 0}+V_{R 0}} \frac{V_{R 0}}{V_{B 0}} \\
b_{z}=b_{p}\left(\frac{A_{e f}}{A_{p}} \frac{V_{R 0}}{\left(V_{B 0}+V_{R 0}\right)}\right)^{3} \\
M=m\left(\frac{A_{e f}}{A_{p}} \frac{V_{R 0}}{\left(V_{B 0}+V_{R 0}\right)}\right)^{2}
\end{gathered}
$$

where $A_{e f}$ is the effective area of the piston, $A_{p}$ is the cross section area of the pipeline, $V_{B 0}$ and $V_{R 0}$ are the initial volumes of the balloon and the reservoir, $p_{0}$ is the absolute pressure in the air spring, $p_{a t}$ is the outside ambient pressure, $b_{p p}$ is the coefficient for the pressure fall from the flow resistance in the pipeline.

In the presented dynamic model, the change of the effective area is neglected, because for the air spring the experiments were made for, this change is very small. However, this model includes damping as well as stiffness characteristics.

\section{FLOW RESISTANCE}

Because of the negligible change in the gas condition and to simplify the mathematical model of gas flow in the pipeline, the equations for incompressible fluid are applied meaning that the pressure drop in the pipeline can be described with:

$$
\begin{aligned}
& \Delta p_{p}=p_{B}-p_{R}=\Delta p_{B}-\Delta p_{R}= \\
& =\rho_{0} \frac{1}{2} k_{\xi} \dot{z}_{p}{ }^{2}+\rho_{0} \frac{1}{2} k_{\lambda} \dot{z}_{p}{ }^{2}=\rho_{0} \frac{1}{2} k_{T} \dot{z}_{p}{ }^{2}
\end{aligned}
$$

where: $\rho_{0}\left(\mathrm{~kg} / \mathrm{m}^{3}\right)$ is the air density for the initial condition, $k_{\xi}$ is the local resistant coefficient, $k_{\lambda}$ is the coefficient of фрицтион losses, $k_{T}$ is the coefficient of total losses in connection pipeline and $\dot{Z}_{p} \quad(\mathrm{~m} / \mathrm{s})$ is the fluid average velocity.

The force produced by pressure drop from the total losses could be analysed as flow resistance and written as follows:

$$
\Delta F_{p}=A_{p}\left(\Delta p_{B}-\Delta p_{R}\right)=A_{p} \rho_{0} \frac{1}{2} k_{T} \dot{z}_{p}{ }^{2}
$$

where $A_{p}\left(\mathrm{~m}^{2}\right)$ is the cross-sectional area of the pipeline.

The equation (9) shows the equivalent damping force from the pipeline. Therefore, the damping coefficient in the equivalent mechanical model of the air spring is:

$$
b_{z}=A_{p} \rho_{0} \frac{1}{2} k_{T}\left(\frac{A_{e f}}{A_{p}} \frac{V_{R 0}}{\left(V_{B 0}+V_{R 0}\right)}\right)^{3}
$$

The total pressure drop in a typical connection pipeline occurs due to the loss of energy in the fluid caused by pipe friction, changes in the direction of flow and formation of the turbulent flow at strict changes of cross sectional-area. These give that the total loss coefficient could be calculated as follows:

$$
k_{T}=k_{\xi c}+k_{\xi e}+k_{\lambda}
$$

where $k_{\xi c}$ and $k_{\xi e}$ are local resistance coefficients for decreasing and increasing of the cross-sectional area along the pipeline respectively, and $k_{\lambda}$ is the coefficient of friction loss along the pipeline. The local loss coefficients depend on the ratio of the diameters $d / D$ and the slope of the diameter change $\theta$ and are usually determined by standardized tables used by engineers in everyday praxis.

The friction coefficient along the pipeline could be determined by:

$$
k_{\lambda}=\frac{L_{p} \lambda}{D_{p}}
$$

where $\lambda$ is the friction coefficient, $L_{p}$ is the length of the pipeline and $D_{p}$ is the diameter of the pipeline.

The friction coefficient $\lambda$ depends on the Reynolds number and the relative roughness $k / D$ and can be determined from the Moody diagram or by using Colebrook-White formula that takes in consideration part of the transient behaviour: 


$$
\lambda=\frac{0,25}{\left[\log _{10}\left(\frac{k}{3,7 D_{p}}+\frac{5,74}{\operatorname{Re}^{0,9}}\right)\right]^{2}}
$$

where: Re is the Reynolds number, $k$ is the equvalent roughness of the pipeline and $D_{p}$ is the pipeline diameter.

The above analysis was made assuming that the flow in the connection pipeline could be approximated as steady flow. This means that every property of the flow at every point remains constant with respect to time. This is not true for the flow in the connection pipeline caused by oscillation of the fluid between air balloon and additional volume. Nevertheless, where the unsteadiness is not too much expressed, unsteady flow can be approximated by assuming that flow is steady at different rates over successive time periods of short duration. This will mean that total losses could be approximated as steady flow losses at the same instantaneous velocity which will lead that the damping coefficient in the new air spring model is dependent on the velocity in the pipe, and therefore on the frequencies. However, the proposed dynamic model of air spring requires constant damping coefficient $b_{z}$ for all frequencies and it represents the average damping coefficient.

\section{SIMULATION AND EXPERIMENTAL RESULTS}

Modelling and simulation of the new dynamic model of the air spring element is performed in the Matlab/Simulink software platform. The model is developed using subsystem requiring input of the basic parameters of the air spring by the user. Subsystem inputs are the positions of the sprung and unsprung masses, and the system output is the force from the air spring.

In order to verify the new dynamic model of an air spring, experimental analyses were performed using air spring Airmatic type 211. The experiment took place at the Faculty of mechanical engineering in Skopje.

The stiffness characteristic of the air spring is calculated as the ratio of the root mean square values (standard deviation) of the force and the position:

$$
c_{z}=\frac{R M S\left(F_{z}\right)}{R M S(z)}
$$

The RMS values of the force and the position are calculated from the time signals considering:

$$
\begin{aligned}
& R M S\left(F_{z}\right)=\left[\frac{1}{n-1} \sum_{i=1}^{n}\left(F_{z i}-\bar{F}_{z}\right)^{2}\right]^{\frac{1}{2}} ; \quad \bar{F}_{z}=\frac{1}{n} \sum_{i=1}^{n} F_{z i} \\
& \operatorname{RMS}(z)=\left[\frac{1}{n-1} \sum_{i=1}^{n}\left(z_{i}-\bar{z}\right)^{2}\right]^{\frac{1}{2}} ; \quad \bar{z}=\frac{1}{n} \sum_{i=1}^{n} z_{i}
\end{aligned}
$$

Experimental results and results obtained by simulation are compared, and a graphical representation of the results is given in figure 3 to figure 5 .
Figure 3 shows frequency dependent stiffness characteristics of an elastic pneumatic element obtained by simulation and experimental measurements for $V_{R 0}=0.00094 \mathrm{~m}^{3}, p_{B}=302 \mathrm{kPa}$ (labelled as V1p1).

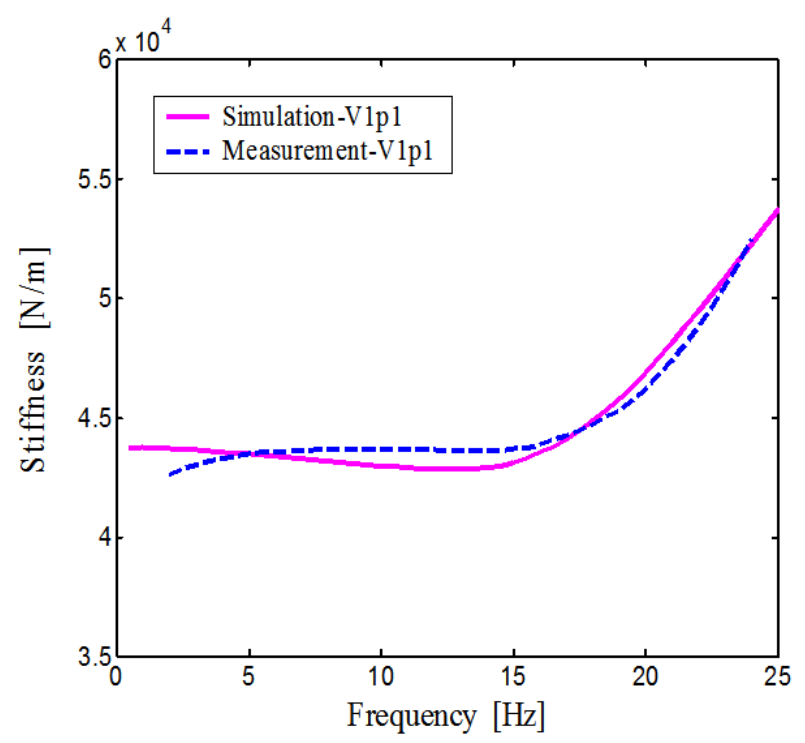

Figure 3. Frequency dependent stiffness characteristics for additional volume 1 and pressure $p 1$

From the curve obtained by measurements, it can be noted a constant value of stiffness in the range from 4 to $15 \mathrm{~Hz}$ and increasing of stiffness for frequencies greater than $15 \mathrm{~Hz}$. The reason for the slight decreasing in stiffness for frequencies less than $4 \mathrm{~Hz}$ is the change of polytrope constant for low frequencies. This change is not included in the dynamic model of pneumatic elastic element.

Diagrams in figures 4 and 5 depict the dependence of the force and displacement in case of sinusoidal disturbance with frequency of $8 \mathrm{~Hz}$ and $16 \mathrm{~Hz}$, respectively.

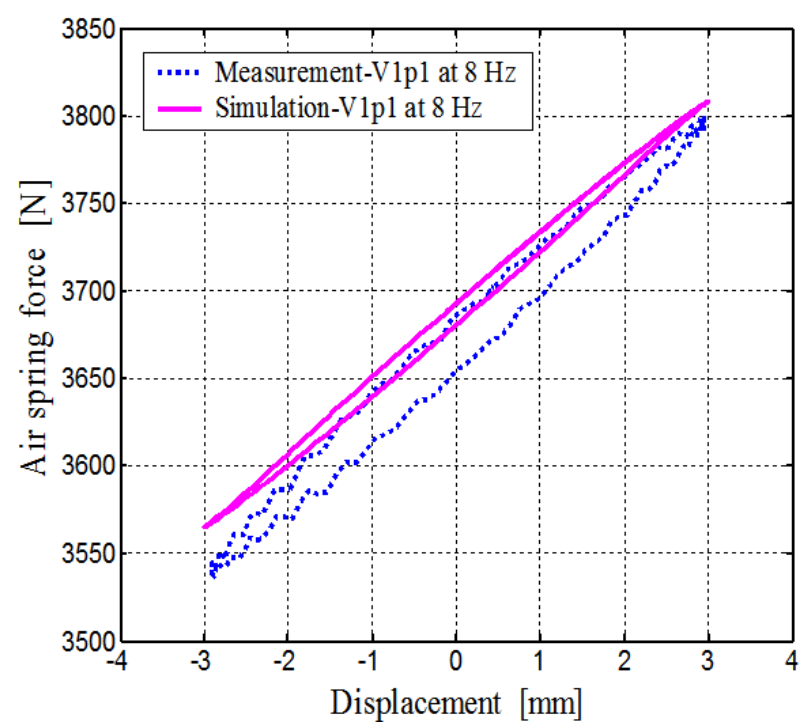

Figure 4. Force - displacement characteristics for V1p1 at 8 $\mathrm{Hz}$ sinusoidal disturbance

Covered area by the closed contour curves, from the force-displacement diagrams, represents the work of stiffness force and work of damping force. The reason for differences of these areas obtained by experimental 
measurements and simulation is the assumed constant mean value of stiffness and constant friction coefficients for all frequencies in the dynamic model. The maximum difference in the force obtained by simulation and the force obtained by measurements is about $30 \mathrm{~N}$, which is less than $1 \%$.

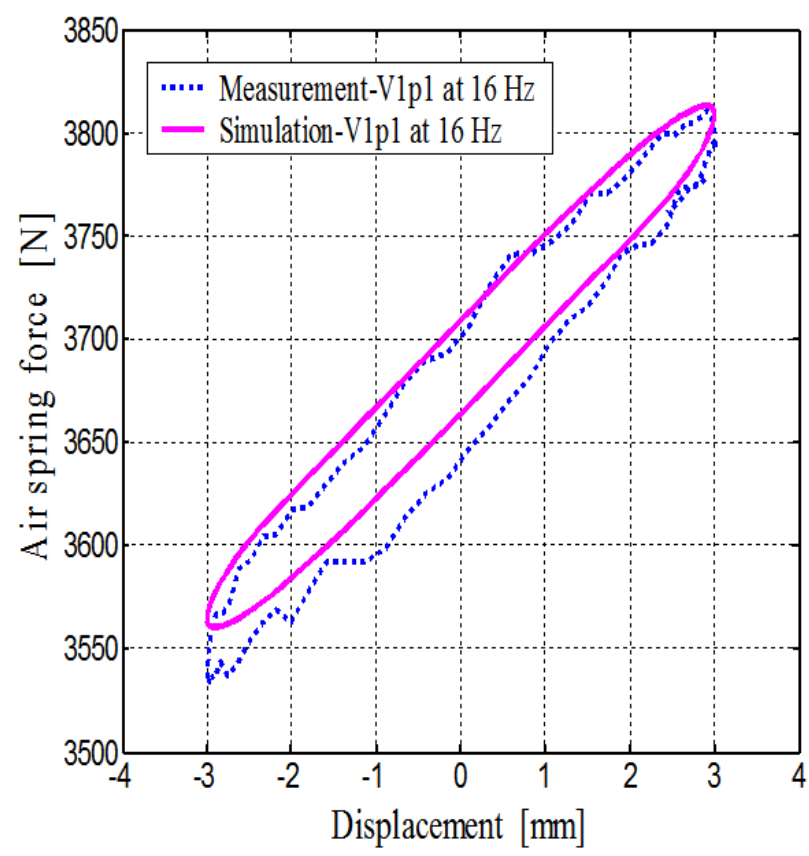

Figure 5. Force - displacement characteristics for V1p1 at $16 \mathrm{~Hz}$ sinusoidal disturbance

Depending on the design parameters of the pipeline, different frequency dependant curves are numerically obtained for switching between the two stiffness characteristics. These curves are presented in figure 6 for different values of the damping. The higher value damping coefficient is presented by the solid state line in figure 6 .

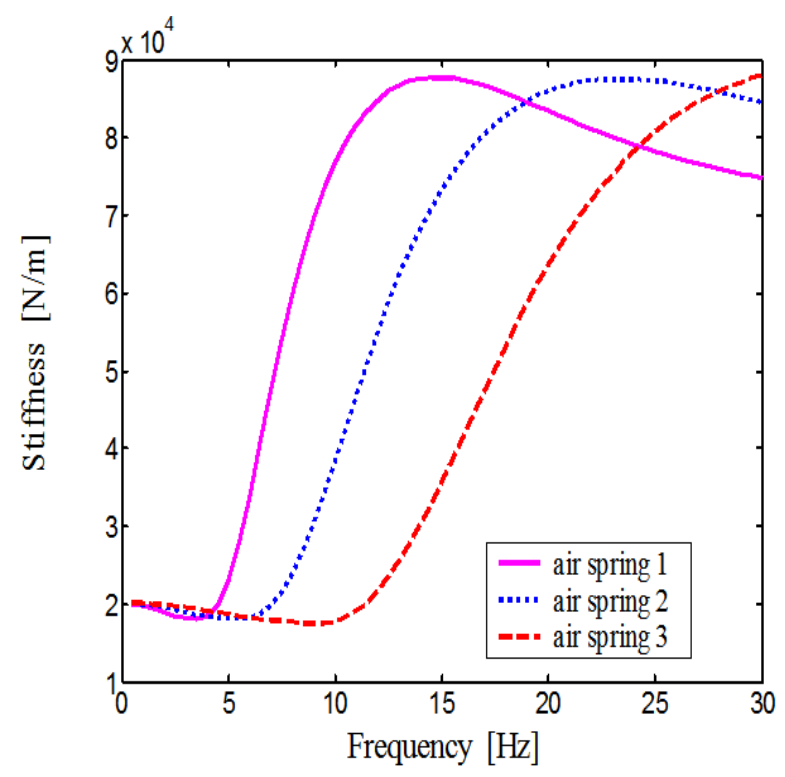

Figure 6. Influence of connection pipeline characteristics on the stiffness characteristics

From the results, it can be concluded that the results obtained by simulation of real pneumatic element, with very small deviations follow the results achieved by experimental measurements.

\section{CONCLUSIONS}

Air springs have established their reputation for low transmissibility coefficients and their ability to vary load capacities easily by changing only the gas pressure within the springs. Even though the air springs are still mainly used in commercial vehicles, lately the trend has pushed them into the higher classes of passenger vehicles as well. The advantages that air spring could offer give the reason for use of these systems in passenger vehicles.

In order to analyse the influence of the air spring parameters on the suspension system performance of passenger vehicles a new dynamic model is proposed. Frequency dependence of the stiffness characteristic implemented in the new model is the main difference between the classical models and the new dynamic model. The proposed dynamic model enables application of the model in simulation without many experimentally obtained parameters because of implementation of appropriate approximations.

The proposed air spring dynamic model is verified by the experiment. The frequency dependence of the stiffness is taken into account and presence of the friction due to the flow resistance in the connection pipeline is implemented in a simplified form.

The proposed methodology for determination of constant average damping coefficient has proved to be accurate enough for analysing vehicle vertical dynamics, although the damping coefficient in real processes is dependent on the velocity in the connection pipe, and therefore on the frequencies.

It is also shown that the design parameters of the connection pipeline that connects two volumes influence the frequency dependence of the stiffness properties. The stiffness frequency dependence could enable the design of an air spring with lower stiffness for lower frequencies and higher stiffness for higher frequencies, which will improve road holding and riding comfort at the frequencies near the sprung mass natural frequency.

\section{REFERENCES}

[1] Gavriloski, V., Danev, D., Angjushev, K.: Mechatronic approach in vehicle suspension system design. Proc. of 12th IFToMM World Congress, Besançon (France), 2007.

[2] Quaglia, G. Sorli, M.: Analysis of vehicular air suspensions. Proc. of Fourth JHPS International Symposium on Fluid Power, pp. 389-384, 1996.

[3] AkopÔn, R.A.: Pnevmaticeskoe podressorivanie avtotransportnìh sredstv. Viça Skola, LÝvov, 1980.

[4] Presthus, M.: Derivation of Air Spring Model Parameters for Train Simulation. Master Thesis, Lulea University of Technology, 2002.

[5] Karnopp, D.: Active and Semi-active Vibration Isolation. Journal of Vibrations and Acoustics, Vol. 117, No. 3B, pp. 177-185, 1995. 
[6] Gavriloski, V., Jovanova, J.: Dynamic behaviour of an air spring element. Journal Machines, Technologies, Materials, 4-5, pp. 24-27, 2010.

\section{РАЗВОЈ НОВОГ ДИНАМИЧКОГ МОДЕЛА ПНЕУМАТСКЕ ОПРУГЕ}

\section{Виктор Гаврилоски, Јована Јованова, Гоце Тасевски, Марјан Ђидров}

Пројектовање система вешања аутомобила инкорпорира компромис између квалитета вожње и стабилности управљања аутомобилом. Промена коефицијената пригушења и крутости омогућава адаптивне карактеристике система вешања. Пнеуматске опруге, као елементи система вешања, омогућавају промене коефицијента пригушења и крутости једноставним концептом са додатним волуменом, што омогућава контролисање промена карактеристике крутости. Истраживања везана за утицај пнеуматске опруге на вертикалну динамику аутомобила изискује употребу модела пнеуматске опруге. Динамички модел пенуматске опруге са карактеристикама које зависе од фреквенције је приказан у овом раду. Отпорност струјања флуида између два волумена је присутна и зависи од дизајна везујућег цевног елемента. Да би се омогућило моделирање без превише експериментално добијених параметара, методологију за дефинисање коефицијента отпора струјања су приказани у овом раду. Верификација динамичког модела пнеуматског елемента је извршена помоћу експеримента. Извршена је анализа симулације и експеримента. 